\title{
Discussion on Practice-oriented Talent Cultivation Mode of Preschool Education
}

\author{
Jichuan Li \\ Primary Education Academy \\ Linyi University \\ Linyi, China \\ E-mail: dongl1972@163.com
}

\begin{abstract}
The particularity of preschool education requires that kindergarten teachers should have a strong practical ability, so the talent cultivation for preschool education shall manifest its practicality. The talent cultivation for preschool education shall reflect the teachers' practice-oriented knowledge-based view and education view. Therefore, it is so important to explore characteristics of practice-oriented talent cultivation mode for preschool education and find approaches to practice-oriented talent cultivation for preschool education.
\end{abstract}

Keywords-practice-orientated; preschool education; talent cultivation mode; teachers' view

\section{INTRODUCTION}

"Opinions on Vigorously Promoting Teacher Education and Curriculum Reform" issued by the Ministry of Education in 2011 clearly states: strengthening teaching practice link, strengthening normal school students' basic skills training, strengthening education probation and providing more opportunities to watch famous teachers giving lectures. With the highlight of practice orientation, "Teacher Education Curriculum Standards" stresses that teachers are reflective practitioners. They realize the professional development course by researching self experience and improving educational behaviors. Teacher education curriculum shall strengthen practical orientation, concern practical problems, and embody new requirements for teachers in educational reform and development. The research found that the practice-oriented talent cultivation mode for preschool education could solve the problem on lack of practice in current teacher education system. The research result has a great significance for improving the professional development of normal school students and cultivating qualified preschool education teachers in line with the social and economic development needs.

\section{The Teachers' VIEW IN THE PRACTICE-ORIENTED} Talent Cultivation Mode for PRESCHOOL Education

\section{A. The teachers' Knowledge View under Practice Orientation}

Teachers' knowledge contains theoretical knowledge and practical knowledge. Theoretical knowledge can be acquired by learning relevant knowledge system. Practical knowledge can be acquired by practicing what they advocate in daily work. It dominates teachers' thinking and behavior and embodies teachers' knowledge in education and teaching behaviors. In fact, only teachers' practical knowledge works in classroom teaching. The term of "teachers' practical knowledge" was put forward by Elbaz. She thought teachers really have a special kind of knowledge which were expressed through practical behaviors and reflection of these behaviors. This kind of knowledge is experiential and implicit and hard to be coded. It sources from "insight" on practice scenario, and later scholars have further developed the connotation of practical knowledge. In a nutshell, teachers' practical knowledge has the characteristics of practicality, individuality, implicitness and situationality, completely opposite to the characteristics of objectivity, universality and neutrality of the intellect-oriented knowledge view.

1) The composition of teachers' knowledge view under practice orientation. On the summary of previous researches, Scholar Chen Xiangming expounded the composition of teachers' practical knowledge. First is education faith. Teachers' faith refers to the view of value depositing in teachers' heart, which involves in understanding of "what's the purpose of education?", "what kind of education is better?" and other problems. Second is self knowledge, including self concept, self evaluation, self teaching efficacy, self regulation and etc. Third is interpersonal knowledge, including perception and understanding, enthusiasm and passion to students. Fourth is situational knowledge, including judging situations and making appropriate choices. Fifth is strategic knowledge, including teachers' understanding, grasp and selection of methods on subject content, subject teaching approach and education theory. Sixth is critical reflection knowledge, about the timing and the type of reflection as well as the development of reflection ability. Thus, teacher's practical knowledge includes experience, faiths, emotions, habits, metaphors, etc. which are excluded by intellect-oriented view of knowledge. It has surpassed Shulman's static analysis on teachers' knowledge, because it has integrated theory and practice together, and approaches to the reality of teachers' educational practice.

2) Source of teachers' practical knowledge. The scholars in the educational cycle have always dispute the source of 
teachers' practical knowledge due to its characteristics of situationality, implicitness and dynamics. One opinion comes from Argyris and Schon. They thought practical theory is the intermediary of "the correlation of basic theory and practical ability. Theories can not be transformed into practical knowledge directly. We can only obtain practical knowledge from practice. Another opinion was represented by Elbaz. She thought as long as individual is able to obtain individual meaning in the course of practicing theoretical knowledge, the theoretical knowledge can be used to direct practice. On the summary of above two opinions we think, on one hand, teachers' practical knowledge is sourced from teachers' review and reflection on educational practice. On the other hand, it comes from teachers' re-interpretation and reflection of educational theory based on their practical background, finally forming practical knowledge that can play an effective role in the professional field. Both sources show that practice and reflection are necessary conditions to obtain practical knowledge for teachers.

\section{B. The Teachers' Pre-Service Education View Based on Practice Orientation}

The answer to "how to cultivate future teachers?" are different for teachers with different view of knowledge. The difference has formed teachers' with different view of education. Looking at the practice-oriented teacher education view, there are three main ideas. First, place a high value on the forming and development of future teachers' practical knowledge. The task of teacher education is to create and set a variety of practical situations to help future teachers acquire practical knowledge. Second, attach great importance to reflection in practice and go forward in the reflection. Teachers' practice and research are not two processes, but two aspects in one process. Third, stress that "learning" refers to "the participation of social practice" rather than "internalization". So, what makes future teachers acquire practical knowledge?

1) Theory - Community of Practice. Practical knowledge is generated from participation in social practice, so learning community comes into being. Learning community has varied interpretations. The definition given by Perry on teachers' learning community basically reflects its essential characteristics. In the framework of Perry's definition, learning community is established in the development of teacher profession. They are an intellectual group with same target and jointly participating in the planning, implementation and reflection of profession development. In the community, learning occurs in action. Professional wisdom is widely spread and knowledge is formed through social approaches. And then key elements, such as "same goal", "participating in the planning jointly" "reflection", "action", "professional wisdom", "sociality" and "construction", are revealed.

2) Cognitive apprenticeship. "Cognitive apprenticeship" was put forward by Educational Psychologist Brown and Collins et al. It stresses to provide a learning environment with the guidance of experts. It tries to imitate the skill passing-on mode in traditional industries to make students adapt to the culture in real practical activities. They believed that formal education is very effective in teaching conceptual and factual knowledge. But it is unproductive in teaching complex cognitive skills. For this purpose, they proposed a teaching mode of "cognitive apprenticeship", attempting to synthesize formal schooling and traditional apprenticeship. "Cognitive apprenticeship" includes four basic elements: content, method, sequence, and sociality. These four basic elements are combined to provide a valuable thinking framework for the support of the teaching mode of cognitive apprenticeship in an effective way.

3) Reflection in Practice. Schon, from the perspective of "professional education", proposed a concept hypothesis of "reflective practitioner". He thought practice situation has liquidity, complexity and value conflict, so professional's action can not be carried out according to established principles and techniques. It needs to frame problem situation and develop approaches to solve problems in the process of interacting with context. Practice is not the application of theory. Practitioner carry out "reflective dialogue" with practical context with the aid of "recognition in action", seek problem-solving approaches and enrich their "recognition in action". The meaning of the introduction of Schon's concept of "reflection in practice" into teacher education field is that it reveals uncertainty of teaching context and starts the research on the role of reflection for improving teaching behavior..

\section{EXPLORATION ON APPROACHES TO THE EDUCATION Talent Cultivation Mode Based on PRACTICE ORIENTATION}

\section{A. Characteristics of the "Practice-Oriented" Talent Cultivation Mode for Preschool Education}

1) Put people first, cultivate talent as needed, combine learning with working and lay stress on practice. Colleges and universities can establish innovation and entrepreneurship funds for students, hold infants' nurse and nutritionist professional qualification training, organize Mandarin, Montessori, and Orff music teacher training, to enable students to obtain the relevant qualifications before graduation, and to provide protection for their successful employment. They can also construct the professional curriculum system and practice training system and establish preschool education chain in the cooperative mode to shorten the distance between profession and occupation. Colleges and universities can implement the academic year mode of " $2.5+0.5 ", " 2+1$ ", education probation, the internship mode of " $4+6$ " (arranging student to kindergarten to practice one week in the first four semesters and to practice six weeks in the fifth semester, and to work on regular post in the sixth semester), because it can combine learning with working, and develop students' professional comprehensive ability and help students realize career orientation and ensure a steady employment rate for professional counterparts.

2) Construct the module curriculum system and build the vocational skills training platform. Construct a curriculum system with vocational ability training as core. The curriculum system includes six modules and one platform, which separately are public compulsory module, 
public elective module, professional theory module, professional skills module, teaching skills module, professional development modules and vocational skills training platform.

In this curriculum system, hours for quality courses accounts for $19.42 \%$. The hours for professional theory courses accounts for $8.72 \%$. The hours for skills courses accounts $29.55 \%$. The hours for direction development accounts for $13.76 \%$. The hours for practical courses accounts for $28.55 \%$. This has basically solved the problems of the absence of practice in the past teaching system.

3) Take the cultivation of innovation ability as main line and optimize course assessment mode. First of all, allow students to participate in innovative and entrepreneurial activities as soon as possible. Schools can set innovation and entrepreneurship credits (compulsory for students), establish innovative and entrepreneurial associations, perfect relevant mechanisms, and create an atmosphere of innovation and entrepreneurship to improve the overall level of innovative and entrepreneurial activity. Secondly, carry out the assessment mode of "separation of teaching and testing" in professional skills courses, such as music, art and dance. Make assessment standards for professional skill courses and organize assessment committee and assessment group, or invite experts and full-time teacher to participate in students' assessment. Use oral test, case analysis, situation creation and solution, teaching simulation, certificate acquirement and other forms of methods to assess five major comprehensive teaching methods courses. This kind of assessment pays more attention to students' creative thinking and can mobilize enthusiasm of students.

\section{B. Approaches to the Practice-Oriented Talent Cultivation Mode for Preschool Education}

1) Developing high-quality skilled personnel training programs according to the needs of the industry. The practice-oriented talent cultivation mode for preschool education shall meet the requirements for talent cultivation target. For this purpose, it shall highlight the cultivation of some key abilities, including occupational behavior ability, mental endurance, survival and development capability and collaborative communication skills, improve two qualities, students' comprehensive ability quality and professional competency quality, lay emphasis on three layers, including general education, professional education and comprehensive quality education, and stress four combinations. In general education, public basic education is content and public course module is support. Professional education is composed of four modules, professional theory, professional teaching, professional skills and practical teaching. Comprehensive quality education mainly includes extracurricular activities, public elective, professional development and etc. The four combinations refer to the combination of general education and professional education, humanistic education and science education, theory teaching and practical teaching, comprehensive quality and personality development. Construct the module course system, which includes three platforms, public courses, professional courses and practical courses. Public course can be divided into public compulsory courses and public elective courses. Professional courses include four modules, professional theory, professional skills, teaching skills and professional development (professional elective). Practical courses include six modules, military training, education probation and practice, social practice, graduation thesis design, innovation and entrepreneurship and post practice. They form a reasonable complete course system.

2) Construct the talent training mode of "three systems and three courses" as main feature. "Three systems and three courses" respectively are "credit system, certificateacquiring system, supervisor system, theory courses, skill course and practical courses". "Recruit students according to their broad profession, cultivate them into different directions and manage them under department". This mode stresses to cultivate talents according to social needs. It constructs a mechanism of "social demand direction, cultivation purpose, evaluation and management". This mode highlights one main line, two aspects and three principals. It insists to the cultivation of basic quality and application ability as main line, faces society and students, and adheres to three principles of normality, practice and innovation.

3) Achieve the education of "two orders, four grafting and six courses". "Two orders" mean to implement orderorientation education according to demands of kindergarten and early education institutions to cultivate high-quality skilled talents. Establish off-campus training base with the support of kindergartens in the province. "Four grafting" means to realize "professional grafting" in four aspects. First is with different subject profession to cultivate interdisciplinary talents. Second is with early childhood development needs to strengthen practical ability training. Third is with preschool institutions to achieve zero distance employment. Fourth is with relevant majors of well-known universities in the country to cultivate talent with international concepts. Starting from discipline cross and discipline integration, "six courses" tries to construct a teaching platform integrating six major professional theory courses, including "preschool psychology," "preschool pedagogy" "preschool health and nutrition", "five major teaching methods for preschool education" "scientific method for preschool education" and "kindergarten management", to train different levels of preschool education talents.

\section{CONCLUSION}

Preschool education talent training should start from social needs and base on practical orientation. Take "focusing on the combination of learning and thinking and the unity of knowledge and practice" as main approach to the innovative talent cultivation mode. Highlight the practicality of the preschool education talent cultivation mode and redevelop talent cultivation program, and strength the supervision and guarantee to the talent training process. The preschool education talents we cultivate shall have preschool education theory knowledge and practical work ability, information application ability and high foreign language level, good professional ethics and humanistic quality, so as 
to cultivate high-quality skilled talents for preschool education.

\section{REFERENCES}

[1] Fan Lianghuo, Teachers' Teaching Knowledge Development Research, Shanghai: East China Normal University Press. 2003.

[2] Jiang Meiling, Teachers' Practical Knowledge Research, Thesis of Doctor of East China Normal University, 2006: 53-54.

[3] Chen Xiangming, Foundation of Theory of Knowledge of Teachers' Practical Knowledge Research, Education Journal, 2009 (4): 52.

[4] Zhang Yan, Preschool Teachers' Professional Development. Beijing: Beijing Normal University Press, 2006: 204.

[5] Gu Rongfang, From Novice to Expert, Preschool Teachers' Professional Development Research, Beijing: Beijing Normal University Press, 2007: 63. 